\title{
In vitro antimicrobial susceptibility and genetic resistance determinants of Streptococcus agalactiae isolated from mastitic cows in Brazilian dairy herds
}

\section{Suscetibilidade in vitro a antimicrobianos e determinantes genéticos de resistência em Streptococcus agalactiae isolados de mastite em rebanhos bovinos brasileiros}

\author{
Juliana Rosa da Silva'; Glei dos Anjos de Carvalho Castro²; Maysa Serpa \\ Gonçalves ${ }^{3}$; Dircéia Aparecida da Costa Custódio ${ }^{4}$; Gláucia Frasnelli Mian ${ }^{5}$; \\ Geraldo Márcio da Costa ${ }^{6 *}$
}

\begin{abstract}
Streptococcus agalactiae is one of the main causative agents of bovine mastitis and is associated with several economic losses for producers. Few studies have evaluated antimicrobial susceptibility and the prevalence of genetic resistance determinants among isolates of this bacterium from Brazilian dairy cattle. This work aimed to evaluate the frequency of the antimicrobial resistance genes ermA, ermB, mefA, tet $O$, tetM, aphA3, and aad-6, and in vitro susceptibility to the antimicrobials amikacin, erythromycin, clindamycin, tetracycline, gentamicin, penicillin, ceftiofur, and cefalotin, and the associations between resistance genotypes and phenotypes among $118 \mathrm{~S}$. agalactiae isolates obtained from mastitic cows in Brazilian dairy herds. Of the resistance genes examined, erm $B$ was found in 19 isolates (16.1\%), tetO in $23(19.5 \%)$, and tet $M$ in $24(20.3 \%)$. The genes ermA, mefA, aphA3, and aad-6 were not identified. There was an association between the presence of genes $\operatorname{erm} B$, tet $M$, and tet $O$ and phenotypic resistance to erythromycin, clindamycin, and tetracycline. Rates of resistance to the tested antibiotics varied, as follows: erythromycin (19.5\%), tetracycline (35.6\%), gentamicin (9.3\%), clindamycin (20.3\%), penicillin (3.4\%), and amikacin (38.1\%); conversely, all isolates were susceptible to ceftiofur and cefalotin. Antimicrobial resistance testing facilitates the treatment decision process, allowing the most judicious choice of antibiotics. Moreover, it enables regional and temporal monitoring of the resistance dynamics of this pathogen of high importance to human and animal health. Key words: Antimicrobial resistance genes. Bovine diseases. Bovine mastitis. GBS, MIC.
\end{abstract}

\section{Resumo}

Streptococcus agalactiae é um dos principais agentes causadores de mastite em bovinos e de consequentes

\footnotetext{
Discente, Curso de Doutorado, Programa de Pós-Graduação em Ciências Veterinárias, Departamento de Medicina Veterinária, Universidade Federal de Lavras, Campus da UFLA, Lavras, MG, Brasil. E-mail: ju rosa silva@hotmail.com

2 Pós-Doutoranda, Departamento de Medicina Veterinária, UFLA, Lavras, MG, Profa, Universidade do Vale do Rio Verde, UNINCOR, Três Corações, MG, Brasil. E-mail: gleicarv@yahoo.com.br

3 Bolsista de IC, Departamento de Medicina Veterinária, UFLA, Lavras MG, Brasil. E-mail: maysa.serpa@yahoo.com.br

4 Bióloga, Departamento de Medicina Veterinária, UFLA, Lavras, MG, Brasil. E-mail: dirceia@dmv.ufla.br

5 Profa ${ }^{a}$, Departamento de Medicina Veterinária, UFLA, Lavras, MG, Brasil. E-mail: glaucia@dmv.ufla.br

6 Prof. Orientador, Departamento de Medicina Veterinária, UFLA, Lavras, MG, Brasil. E-mail: gmcosta@dmv.ufla.br

Author for correspondence
} 
perdas econômicas aos produtores. Poucos estudos que avaliaram a susceptibilidade a antimicrobianos e a presença de determinantes genéticos de resistência para este agente em bovinos leiteiros do Brasil. Este trabalho teve por objetivo avaliar a frequência dos genes de resistência a antimicrobianos $\operatorname{erm} A$, erm $B$, mefA, tet $O$, tet $M$, aph $A 3$, aad-6, bem como a susceptibilidade in vitro aos antimicrobianos amicacina, eritromicina, clindamicina, tetraciclina, gentamicina, penicilina, ceftiofur e cefalotina, e as associações entre genótipos e fenótipos de resistência em 118 isolados de $S$. agalactiae provenientes de casos de mastite em rebanhos bovinos brasileiros. Dentre os genes de resistência pesquisados, erm $B$ foi encontrado em 19 isolados (16,1\%), tetO em 23 (19,5\%) e tetM em 24 (20,3\%). Os genes ermA, $m e f A$, apha3 e aad6 não foram detectados. Verificou-se associação entre a presença dos genes erm $B$, tet $M$ e tet $O$ e os fenótipos de resistência à eritromicina, clindamicina e tetraciclina. Foram encontrados diferentes índices de resistência aos antibióticos testados: Eritromicina (19,5\%), tetraciclina (35,6\%), gentamicina $(9,3 \%)$, clindamicina $(20,3 \%)$, penicilina $(3,4 \%)$ e amicacina $(38,1 \%)$. Todos os isolados foram susceptíveis ceftiofur e cefalotina. Os testes de resistência aos antimicrobianos auxiliam na tomada de decisões relacionadas aos tratamentos, permitindo a escolha mais criteriosa dos antimicrobianos e o acompanhamento espaço-temporal da dinâmica de resistência para este patógeno tão relevante na saúde humana e animal.

Palavras-chave: CIM. Doenças de bovinos. GBS. Genes de resistência a antimicrobianos. Mastite bovina.

\section{Introduction}

Mastitis is the most common and costly infectious disease affecting dairy farms worldwide (KEEFE, 2012). This condition affects the quality and quantity of milk produced, and results in treatmentrelated expenses and losses due to milk disposal and replacement of chronically affected animals (RUEGG, 2012; SANTOS; FONSECA, 2007). It is a multifactorial disease involving environmental conditions, aspects inherent to the animals themselves, and infectious factors. Regarding this aspect, more than 140 different microorganisms have been implicated in its etiology (RIBEIRO et al., 2006).

The bacterium Streptococcus agalactiae is well adapted to the bovine mammary gland, and generally causes acute clinical diseases and persistent subclinical infections (HILLERTON et al., 2004). It is highly contagious and leads to mastitis associated with a very low rate of spontaneous cure. In Brazil, $S$. agalactiae is one of the main etiologic agents of bovine mastitis, with an estimated average prevalence in herds of $60 \%$ (KEEFE, 2012). Affected animals act as important reservoirs in the herd, and transmission predominantly occurs during the milking period (BAL et al., 2010).
Besides its role in bovine mastitis, $S$. agalactiae is an important public health concern. In humans, this microorganism colonizes the urogenital and gastrointestinal tracts, and may lead to sepsis, pneumonia, neonatal meningitis, mastitis in lactating women, and high mortality rates among immunocompromised individuals (JOHRI et al., 2006; MAIONE et al., 2005; ZADOKS et al., 2011). It is also an emergent pathogen in aquaculture, causing sepsis or meningoencephalitis among freshwater, marine, and estuarine fishes with high rates of morbidity and mortality (EVANS et al., 2002).

Since the introduction of penicillin in the 1940s, antimicrobials have been extensively used for bacterial infection control, both in human medicine and for the improvement of animal health and wellbeing (BARLOW, 2011). Therapeutic intervention has a central role in the control of bovine mastitis, leading to frequent antimicrobial use on farms (OLIVEIRA; RUEGG, 2014). However, the efficacy of such agents is compromised when resistance arises, a problem that affects animal health and has public health implications. Resistance is influenced by intensive and indiscriminate use of antimicrobials and the frequency with which mutations occur in 
resistance genes (JOO et al., 2016; SCHWARZ et al., 2001).

Efficient, permanent prevention and early treatment are crucial goals for the adequate control of mastitis, as non-treated cases generally develop into a chronic condition, resulting in permanent losses (TENHAGEN et al., 2006). Intramammary infusions of high doses of one or more antibiotics, principally penicillins, cephalosporins, tetracyclines, aminoglycosides, and macrolides, are often used to treat bovine mastitis (KEEFE, 2012). Thus, determining resistance patterns and detecting the dissemination of genetic elements conferring resistance are important in aiding the treatment decision process.

Studies that contribute to our understanding of the susceptibility profiles of pathogenic agents responsible for dairy cow mastitis are therefore indispensable (ERSKINE et al., 2003). Such investigations allow continuous epidemiologic monitoring of bacterial antimicrobial susceptibility, and enable the detection of resistant strains. Notably, patterns of resistance to antimicrobials used for mastitis must be continuously monitored as they may vary over time, among countries, and even between different farms from a same region (VINTOV et al., 2003).

Little research has been conducted concerning the antimicrobial susceptibility profiles of $S$. agalactiae strains isolated from mastitis-affected cows in Brazilian herds. In the few studies performed, causative agent identification has been limited to the genus level and the disc diffusion method used, which, although internationally standardized, is more error-prone than the minimal inhibitory concentration (MIC) approaches (FERREIRA et al., 2010; OLIVEIRA et al., 2011).

The objective of this work was to evaluate in vitro antimicrobial susceptibility and the presence of genetic antibiotic resistance determinants among S. agalactiae strains isolated from mastitic cows in Brazilian dairy herds.

\section{Materials and Methods}

This study was conducted at the Laboratório de Microbiologia of the Departamento de Medicina Veterinária/DMV - Universidade Federal de Lavras/ UFLA, Lavras, Brazil, using 118 S. agalactiae strains isolated from bovine mastitis cases in the Northeastern $(n=10)$, Southeastern $(n=95)$, and Southern $(n=13)$ regions of Brazil. The isolates used had been stored at $-70^{\circ} \mathrm{C}$ at the abovementioned laboratory, and were kindly made available by scientists affiliated to research and teaching institutions in the aforementioned regions.

\section{Molecular tests}

The $S$. agalactiae strains were grown on Trypticase soy agar (HiMedia ${ }^{\circledR}$, Mumbai, India) supplemented with $5 \%$ ovine blood at $37^{\circ} \mathrm{C}$ for 24 48 hours. After this period, they were transferred to brain-heart infusion broth (Brain Heart Infusion) (Sigma-Aldrich ${ }^{\circledR}$, Bengaluru, India) and cultured at $37^{\circ} \mathrm{C}$ for a further $24-48$ hours. Genomic DNA was then extracted using a Wizard ${ }^{\circledR}$ Genomic DNA Purification Kit (Promega ${ }^{\circledR}$, Madison, WI, USA), per the standard protocol for Gram-positive bacteria.

Antimicrobial resistance genes were detected using polymerase chain reaction (PCR) in a Peltier Thermal Cycler Multi-Purpose device (Biocycle ${ }^{\circledR}$, Hangzhou, China), using conditions and primers previously described in the literature (Table 1). When necessary, optimization of these reactions was performed. We tested for the genes ermA and erm $B$ (conferring cross-resistance to macrolides, lincosamides, and streptogramins), mefA (encoding an efflux pump resulting in macrolide resistance), tet $O$ and tetM (causing tetracycline resistance by ribosomal protection), and aphA3 and aad-6 (enabling aminoglycoside resistance). To evaluate the reproducibility of PCR results, strains were re-tested after each run. Positive and negative controls were included during amplification of each gene. Reaction specificity was evaluated by product size and the presence of a single amplicon. 
PCR products were separated by electrophoresis using $1 \times$ Tris-acetate-EDTA buffer $(0.04 \mathrm{M}$ Trisacetate and $0.001 \mathrm{M}$ EDTA) and a 1.5\% agarose gel (Invitrogen Brasil, São Paulo, Brazil) stained with GelRed $^{\mathrm{TM}}$ (Biotium $^{\circledR}$, Fremont, CA, USA). One hundred-base pair and 1-kb DNA ladders
(New England Biolabs ${ }^{\circledR}$ Inc., Ipswich, MA, USA) were also loaded onto each gel. Gel images were recorded in a transilluminator (L-Pix Chemi Photo Digitizer; Loccus Biotecnologia, Cotia, Brazil) for later analysis.

Table 1. Primers used in the detection of antimicrobial resistance genes in S. agalactiae isolated from mastitis in Brazilian dairy herds and size of PCR products.

\begin{tabular}{|c|c|c|c|}
\hline Target Gene & Product Size & Sequence (5'-3') & References \\
\hline ermA & $640 \mathrm{pb}$ & $\begin{array}{l}\text { F:5'-TCTAAAAAGCATGTAAAAGA-3' } \\
\text { R:5'-CTTCGATAGTTTATTAATATTAGT-3' }\end{array}$ & (SUTCLIFFE et al., 1996) \\
\hline ermB & $640 \mathrm{pb}$ & $\begin{array}{l}\text { F:5'-GAAAAGRTACTCAACCAAATA-3' } \\
\text { R:5'AGTAACGGTACTTAAATTGTTTAC-3' }\end{array}$ & (SUTCLIFFE et al., 1996) \\
\hline mefA & $328 \mathrm{pb}$ & $\begin{array}{l}\text { F:5'-AGTATCATTAATCACTAGTGC-3' } \\
\text { R:5'-TTCTTCTGGTACTAAAAGTGG-3' }\end{array}$ & (SUTCLIFFE et al., 1996) \\
\hline tet $M$ & $359 \mathrm{pb}$ & $\begin{array}{l}\text { F:5'-GTGGAGTACTACATTTACGAG-3' } \\
\text { R:5'-GAAGCGGATCACTATCTGAG-3' }\end{array}$ & (POYART et al., 1995) \\
\hline tetO & $538 \mathrm{pb}$ & $\begin{array}{l}\text { F:5'-GCGGAACATTGCATTTGAGGG-3' } \\
\text { R:5'-CTCTATGGACAACCCGACAGAAG-3' }\end{array}$ & (CLERMONT et al., 1997) \\
\hline $\operatorname{aph} A 3$ & $848 \mathrm{pb}$ & $\begin{array}{l}\text { F:5'-GGGGTACCTTTAAATACTGTAG-3' } \\
\text { R:5'-TCTGGATCCTAAAACAATTCATCC-3' }\end{array}$ & (POYART et al., 1995) \\
\hline aad-6 & $978 \mathrm{pb}$ & $\begin{array}{l}\text { F:5'-AGAAGATGTAATAATATAG-3' } \\
\text { R:5'-CTGTAATCACTGTTCCCGCCT-3' }\end{array}$ & $\begin{array}{l}\text { (POYART-SALMERON et } \\
\text { al., 1990) }\end{array}$ \\
\hline
\end{tabular}

MIC Tests

MIC assays, according to which isolates were classified as susceptible or resistant, were estimated using the microdilution method following Clinical and Laboratory Standards Institute (CLSI) guidelines (CLSI, 2008). Sterile microplates containing Mueller Hinton broth adjusted with the divalent cations $\mathrm{Ca}^{2+}$ and $\mathrm{Mg}^{2+}$ (CAMHB;
HiMedia $^{\circledR}$ ) and supplemented with 5\% equine serum were used. The antibiotics amikacin, erythromycin, clindamycin, tetracycline, gentamicin, penicillin, ceftiofur, and cefalotin (Sigma-Aldrich ${ }^{\circledR}$, St. Louis, MO, USA) were solubilized and diluted to test concentrations according to CLSI specifications (CLSI, 2008) (Table 2). 
Table 2. Antibiotic concentrations $(\mu \mathrm{g} / \mathrm{mL})$ used to determine Minimal Inhibitory Concentrations - MIC, in $S$. agalactiae isolated from mastitis in Brazilian dairy herds.

\begin{tabular}{cc}
\hline Antibiotic & Concentration $(\mu \mathrm{g} / \mathrm{mL})$ \\
\hline Amikacin & $256-0.5$ \\
Erythromycin & $32-0.06$ \\
Tetracycline & $128-0.25$ \\
Gentamicin & $128-0.25$ \\
Penicillin & $8-0.015$ \\
Ceftiofur & $32-0.06$ \\
Clindamycin & $16-0.03$ \\
Cefalotin & $8-0.015$ \\
\hline
\end{tabular}

Strains were first cultured in Trypticase soy agar $\left(\right.$ HiMedia $^{\circledR}$ ) supplemented with $5 \%$ ovine blood at $37^{\circ} \mathrm{C}$ for $24-48$ hours. Suspensions of each bacterial strain were then prepared in $0.9 \%$ saline solution and adjusted to a McFarland turbidity standard of 0.5 , or $1.5 \times 10^{8} \mathrm{CFU} / \mathrm{mL}$. Five microliters of bacterial suspension was added to each well of the microplate containing CAMHB and antibiotics at the appropriate concentrations. The plates were subsequently agitated and incubated for 24 hours at $37^{\circ} \mathrm{C}$. All tests were performed in duplicate, using negative and positive controls for bacterial growth. After incubation, MICs (the lowest concentration of each antibiotic at which it was not possible to visually detect bacterial growth) were determined. Results were evaluated following CLSI standards (CLSI, 2008).
Associations between the presence/absence of antimicrobial resistance genes and phenotypic resistance to erythromycin, clindamycin, and tetracycline were statistically evaluated using SPSS 20.0 software (IBM Corp., Armonk, NY, USA) using Fisher's exact test at a 99\% confidence level $(\mathrm{p} \leq 0.01)$.

\section{Results}

Based on the MICs measured, rates of resistance among the $S$. agalactiae isolates $(\mathrm{n}=118)$ varied between the antibiotics tested, as follows: erythromycin (19.5\%), tetracycline $(35.6 \%)$, gentamicin $(9.3 \%)$, clindamycin $(20.3 \%)$, penicillin (3.4\%), and amikacin (38.1\%); however, all isolates were susceptible to ceftiofur and cefalotin. MIC distributions are compiled in Table 3. 
Table 3. Distribution of Minimal Inhibitory Concentrations for eight antimicrobials in S. agalactiae isolated from mastitis from Brazilian dairy herds.

\begin{tabular}{cccccccccccccc}
\hline CONC. $(\mu \mathrm{g} / \mathrm{mL})$ & $>256$ & 256 & 128 & 64 & 32 & 16 & 8 & 4 & 2 & 1 & $<0.5$ & $\mathrm{~T} . \mathrm{R}$. & $\mathrm{T} . \mathrm{S}$ \\
\hline AMIKACIN & 0 & 0 & 0 & 18 & 55 & 36 & 3 & 5 & 0 & 0 & 1 & 73 & 45 \\
& $\mathrm{R}$ & $\mathrm{R}$ & $\mathrm{R}$ & $\mathrm{R}$ & $\mathrm{I}$ & $\mathrm{S}$ & $\mathrm{S}$ & $\mathrm{S}$ & $\mathrm{S}$ & $\mathrm{S}$ & $\mathrm{S}$ & $38.10 \%$ & $61.90 \%$ \\
CONC. $(\mu \mathrm{g} / \mathrm{mL})$ & $>128$ & 128 & 64 & 32 & 16 & 8 & 4 & 2 & 1 & 0.5 & $<0.25$ & $\mathrm{~T} . \mathrm{R}$. & $\mathrm{T} . \mathrm{S}$. \\
TETRACYCLINE & 4 & 1 & 13 & 20 & 4 & 0 & 0 & 1 & 4 & 5 & 66 & 42 & 76 \\
& $\mathrm{R}$ & $\mathrm{R}$ & $\mathrm{R}$ & $\mathrm{R}$ & $\mathrm{R}$ & $\mathrm{R}$ & $\mathrm{I}$ & $\mathrm{S}$ & $\mathrm{S}$ & $\mathrm{S}$ & $\mathrm{S}$ & $35.60 \%$ & $64.40 \%$ \\
GENTAMICIN & 0 & 0 & 0 & 0 & 0 & 11 & 51 & 38 & 9 & 6 & 3 & 11 & 107 \\
& $\mathrm{R}$ & $\mathrm{R}$ & $\mathrm{R}$ & $\mathrm{R}$ & $\mathrm{R}$ & $\mathrm{I}$ & $\mathrm{S}$ & $\mathrm{S}$ & $\mathrm{S}$ & $\mathrm{S}$ & $\mathrm{S}$ & $9.30 \%$ & $90.70 \%$ \\
CONC. $(\mu \mathrm{g} / \mathrm{mL})$ & $>32$ & 32 & 16 & 8 & 4 & 2 & 1 & 0.5 & 0.25 & 0.12 & $<0.06$ & $\mathrm{~T} . \mathrm{R}$. & $\mathrm{T} . \mathrm{S}$. \\
ERYTHROMYCIN & 17 & 0 & 0 & 1 & 0 & 0 & 2 & 3 & 0 & 2 & 93 & 23 & 95 \\
& $\mathrm{R}$ & $\mathrm{R}$ & $\mathrm{R}$ & $\mathrm{R}$ & $\mathrm{R}$ & $\mathrm{R}$ & $\mathrm{R}$ & $\mathrm{I}$ & $\mathrm{S}$ & $\mathrm{S}$ & $\mathrm{S}$ & $19.50 \%$ & $80.50 \%$ \\
CEFTIOFUR & 0 & 0 & 0 & 0 & 0 & 0 & 0 & 0 & 0 & 0 & 118 & 0 & 118 \\
& $\mathrm{R}$ & $\mathrm{R}$ & $\mathrm{R}$ & $\mathrm{R}$ & $\mathrm{I}$ & $\mathrm{S}$ & $\mathrm{S}$ & $\mathrm{S}$ & $\mathrm{S}$ & $\mathrm{S}$ & $\mathrm{S}$ & $0 \%$ & $100 \%$ \\
CONC.( $\mu \mathrm{g} / \mathrm{mL})$ & $>16$ & 16 & 8 & 4 & 2 & 1 & 0.5 & 0.25 & 0.12 & 0.06 & $<0.03$ & $\mathrm{~T} . \mathrm{R}$. & $\mathrm{T} . \mathrm{S}$. \\
CLINDAMYCIN & 20 & 0 & 0 & 3 & 0 & 1 & 1 & 2 & 0 & 18 & 73 & 24 & 94 \\
& $\mathrm{R}$ & $\mathrm{R}$ & $\mathrm{R}$ & $\mathrm{R}$ & $\mathrm{I}$ & $\mathrm{I}$ & $\mathrm{S}$ & $\mathrm{S}$ & $\mathrm{S}$ & $\mathrm{S}$ & $\mathrm{S}$ & $20.30 \%$ & $79.70 \%$ \\
CONC.( $\mu \mathrm{g} / \mathrm{mL})$ & $>8$ & 8 & 4 & 2 & 1 & 0.5 & 0.3 & 0.12 & 0.06 & 0.03 & $<0.015$ & $\mathrm{~T} . \mathrm{R}$. & $\mathrm{T} . \mathrm{S}$. \\
PENICILLIN & 0 & 0 & 0 & 0 & 1 & 2 & 1 & 8 & 28 & 38 & 40 & 4 & 114 \\
& $\mathrm{R}$ & $\mathrm{R}$ & $\mathrm{R}$ & $\mathrm{R}$ & $\mathrm{I}$ & $\mathrm{I}$ & $\mathrm{I}$ & $\mathrm{S}$ & $\mathrm{S}$ & $\mathrm{S}$ & $\mathrm{S}$ & $3.40 \%$ & $96.60 \%$ \\
CEFALOTIN & 0 & 0 & 0 & 0 & 0 & 3 & 82 & 29 & 4 & 0 & 0 & 0 & 118 \\
& $\mathrm{~S}$ & $\mathrm{~S}$ & $\mathrm{~S}$ & $\mathrm{~S}$ & $\mathrm{~S}$ & $\mathrm{~S}$ & $\mathrm{~S}$ & $\mathrm{~S}$ & $\mathrm{~S}$ & $\mathrm{~S}$ & $\mathrm{~S}$ & $0 \%$ & $100 \%$ \\
\hline
\end{tabular}

Highlighted cells represent resistant isolates, i.e. those with MIC $\geq$ standard cut-off values for each antimicrobial. R-Resistant; I-Intermediate; S-Sensitive, T.R. Total of Resistants, T.S. Total of Sensitives, CONC. Concentration.

Of the resistance genes tested, $\operatorname{erm} B$ was found in 19 isolates $(16.1 \%)$, tet $O$ in $23(19.5 \%)$, and tet $M$ in $24(20.3 \%)$. Genes ermA, mefA, aphA3, and aad6 were not detected in any of the isolates.

Associations between phenotypic resistance to erythromycin, clindamycin, and tetracycline and presence of the resistance genes $\operatorname{erm} B$, tet $M$, and tet $O$ are reported in Table $4(\mathrm{p}<0.01)$. Of the $19 \mathrm{ermB}$-positive isolates, 17 (89.5\%) were phenotypically resistant to erythromycin; however, six erythromycin-resistant isolates did not carry this gene. Regarding clindamycin, 18 (94.7\%) of the $19 \mathrm{ermB}$-positive isolates were phenotypically resistant, but ermB was not detected in six clindamycin-resistant isolates. 
Table 4. Comparison of genotypic and phenotypic resistance to antibiotics in S. agalactiae isolated from mastitis in Brazilian dairy herds.

\begin{tabular}{|c|c|c|c|c|c|c|}
\hline \multirow[b]{2}{*}{ Antibiotics } & \multicolumn{3}{|c|}{ Characteristics of Isolates } & \multirow[b]{2}{*}{$\mathrm{F}+/ \mathrm{G}^{-}{ }^{\mathrm{d}}$} & \multicolumn{2}{|c|}{ Association $^{\mathrm{a}}$} \\
\hline & Genes & $\mathrm{F}+/ \mathrm{G}^{\mathrm{b}}$ & $\mathrm{F}-/ \mathrm{G}^{-\mathrm{c}}$ & & $\mathrm{F}-/ \mathrm{G}+^{\mathrm{e}}$ & $\mathrm{p}$ \\
\hline Erythromycin & ermB & 17 & 93 & 6 & 2 & $<0.001$ \\
\hline Clindamycin & ermB & 18 & 93 & 6 & 1 & $<0.001$ \\
\hline \multirow[t]{2}{*}{ Tetracycline } & tetO & 21 & 74 & 21 & 2 & $<0.001$ \\
\hline & tetM & 19 & 71 & 23 & 5 & $<0.001$ \\
\hline Amikacin & aphA3/aad6 & 0 & 73 & 45 & 0 & $<0.001$ \\
\hline Gentamicin & aphA3/aad6 & 0 & 107 & 11 & 0 & $<0.001$ \\
\hline
\end{tabular}

${ }^{a}$ Association between resistance phenotypes and resistance genes. Fisher's Exact Test $(\mathrm{p}<0.01)$

${ }^{b}$ Number of isolates expressing the resistance phenotype for the named antibiotic $(\mathrm{F}+)$ that have the indicated gene $(\mathrm{G}+)$.

${ }^{\mathrm{c}}$ Number of isolates not expressing the resistance phenotype for the named antibiotic (F-) that do not have the indicated gene (G-).

${ }^{\mathrm{d} N u m b e r}$ of isolates expressing the resistance phenotype for the named antibiotic $(\mathrm{F}+)$ that do not have the indicated gene (G-).

${ }^{\mathrm{e}}$ Number of isolates not expressing the resistance phenotype for the named antibiotic (F-) that have the indicated gene (G+).

Concerning the association between genes conferring tetracycline resistance and phenotypic resistance to this antimicrobial, 95.7 and $98.3 \%$ of $t e t M$-positive and tet $O$-positive isolates, respectively, were phenotypically resistant. Four isolates lacking tet $M$ and tet $O$ were resistant to tetracycline. Ten tetracycline-susceptible isolates carried one or both of these genes, with three carrying both, two tet $O$ alone, and five tet $M$ alone. We also verified the association between carriage of tet $O$ and $e r m B$, given that $89.5 \%$ of ermB-positive strains carrying tet $O$.

\section{Discussion}

The implementation of programs for the control and prevention of bovine mastitis is of great importance considering the losses that this disease causes for producers and the industry as a whole. The measures comprising such programs include the early treatment of clinical cases and dry cow therapy. These actions are fundamental for effective mastitis control, since untreated cases generally become chronic, resulting in permanent losses (TENHAGEN et al., 2006). Considering this, evaluation of resistance patterns and the dissemination of genetic elements conferring resistance is crucial in determining which antimicrobials may be used in the treatment of affected animals, as well as in monitoring the spatial and temporal dynamics of antimicrobial resistance.

MIC values to antimicrobials are showed in Table 3. Erythromycin resistance has been documented worldwide in studies concerning $S$. agalactiae strains of human and bovine origin. In the United States and Europe, resistance rates of approximately 4-50\% have been reported (DIPERSIO; DIPERSIO, 2006; DOGAN et al., 2005; GUÉRIN-FAUBLÉE et al., 2002; SADOWY et al., 2010), while in Brazil, estimates have been lower than $10 \%$ (CORREA et al., 2011; DUARTE et al., 2004, 2005; PALMEIRO et al., 2010). However, of the Brazilian bovine isolates examined by Pinto et al. (2013), 27.6\% were resistant to this antibiotic, a higher value than that recorded in the present work (19.5\%).

High rates of tetracycline resistance (60-90\%) have been reported among both human and bovine $S$. agalactiae isolates (DOGAN et al., 2005; DUARTE et al., 2004; GAO et al., 2012; PINTO et al., 2013; RATO et al., 2013). In the current work, resistance to this antimicrobial was found to be approximately $35.6 \%$. Such elevated resistance to tetracycline can 
be explained by its indiscriminate use over many years to combat several animal diseases.

Cefazolin and cefoperazone resistance was not detected by Rato et al. (2013) in their analysis of 60 mastitis-associated S. agalactiae strains from Portugal. Similarly, in the present work, all isolates were susceptible to cefalotin and ceftiofur. These antimicrobials are first and third-generation cephalosporins, respectively, as are cefazolin and cefoperazone. Corroborating our results, Lindeman et al. (2013) also found high levels of ceftiofur and cefalotin susceptibility among $S$. agalactiae isolates from North American dairy cattle.

High penicillin susceptibility rates have been described in previous studies to $S$. agalactiae isolates from mastitic cows. In the present work, consistent with such investigations (GUÉRIN-FAUBLÉE et al., 2002; MINST et al., 2012; RATO et al., 2013), most isolates $(96.6 \%)$ were susceptible to penicillin, indicating that this antibiotic is a viable option for the treatment of mastitis. In humans, penicillin is the recommended first-line treatment for $S$. agalactiae infections for all age groups, in addition to being administered prophylactically to pregnant women (BOLUKAOTO et al., 2015; VERANI et al., 2010).

Variable levels of resistance to gentamicin have been recorded among bovine $S$. agalactiae isolates. Gao et al. (2012), in a study of 55 S. agalactiae isolates collected from Chinese cows, reported that $29.4 \%$ were resistant to this antimicrobial. In contrast, all 85 strains of this bacterium recovered from Brazilian cattle in an investigation by Duarte et al. (2004) were found to be resistant. In addition, Rato et al. (2013) documented a resistance rate of $80.6 \%$ among 108 isolates collected from Portuguese cows. The results of the present study differ somewhat in this respect, given that only $9.3 \%$ of the tested strains were resistant to gentamicin, while $38.1 \%$ were resistant to amikacin, another aminoglycoside antibiotic.

The genetic resistance determinants of $S$. agalactiae identified in the present work (Table
4) have been widely documented in previous studies. The genes ermA and ermB determine cross-resistance to erythromycin and clindamycin. In this study, ermB was found in $16.1 \%$ of strains and its presence was associated with resistance to these antibiotics, whereas erm $A$ was not detected. Prior investigations have described $\operatorname{erm} B$ as the most common erm gene in bovine $S$. agalactiae isolates, while ermA is more frequent among human strains (DUARTE et al., 2004; DUTRA et al., 2014). Six isolates showed phenotypic resistance to erythromycin and clindamycin despite not carrying ermA or ermB. This might be explained by the great variety of genetic mechanisms that may be associated with a single resistance phenotype. For instance, the isolates in question may harbor less frequently observed resistance determinants such as erm $C$, ermF, and/or erm $T$, all of which have been described in streptococci (ROBERTS, 2008).

The tetracycline resistance determinants tet $O$ and $t e t M$ were present in the studied strains at very similar frequencies (19.5 and 20.3\%, respectively), and both were associated with phenotypic resistance to tetracycline. These are the most commonly identified tet genes among both bovine and human $S$. agalactiae isolates (DOGAN et al., 2005; DUARTE et al., 2005; DUTRA et al., 2014; PINTO et al., 2014), while others determinants such as tetS and tet $K$ being observed less frequently (DUARTE et al., 2004; RATO et al., 2013). Four isolates exhibiting phenotypic tetracycline resistance harbored neither tet $M$ nor tet $O$, suggesting the presence of a different tet gene, such as tetS or tetK. Further investigation of these isolates is required to confirm this hypothesis. Carriage of both $\operatorname{tet} O$ and tet $M$, a phenomenon previously reported by Duarte et al. (2004), was observed in three isolates. However, 10 tetracycline-susceptible isolates carried one or both of these genes, with three carrying both, two tet $O$ alone, and five tet $M$ alone. The reasons that resistance genes are not always expressed need to be further evaluated. Possible explanations include promoter absence, weakness, or distance, and the 
presence of mutations in the genes in question, as suggested by Gao et al. (2012). We found that $89.5 \%$ of strains carrying erm $B$ also carried tet $O$, an association that has been previously documented.

The importance of monitoring genetic elements involved in tetracycline resistance has been emphasized in prior reports, as tet genes are often found in mobile genetic elements that also encode resistance to macrolides, lincosamides, and chloramphenicol (CHOPRA; ROBERTS, 2001). Associations between tet and erm genes, owing to their presence in the same mobile genetic element, have been described several times in relation to Streptococcus pyogenes and Streptococcus pneumoniae, but only rarely with respect to $S$. agalactiae (HAENNI et al., 2010; VARALDO et al., 2009), and their prevalence in this latter may be underestimated.

The mefA gene and the corresponding $\mathrm{M}$ phenotype (erythromycin resistance and clindamycin susceptibility) were not detected among the isolates tested. Similarly, neither Palmeiro et al. (2010) nor Rato et al. (2013) detected this gene or phenotype in their studies of $S$. agalactiae taken from bovine and human sources, respectively.

The genes aphA3 and aad-6, which confer resistance to aminoglycosides, were not identified in the current work, consistent with the high rate of gentamicin susceptibility recorded. These genes have been reported in human and bovine $S$. agalactiae strains in other countries, associated with infections resistant to one or more aminoglycoside antimicrobials (GAO et al., 2012; POYART et al., 2003). To date, however, there have been no reports of these genes in bovine $S$. agalactiae strains isolated from Brazilian dairy herds.

In summary, the bovine $S$. agalactiae isolates studied in this work were heterogeneous with respect to the genetic resistance determinants and phenotypic resistance. The high rates of resistance to tetracycline, clindamycin, and erythromycin observed suggest that the utility of these antimicrobial agents for the treatment of infected cows is limited, and imply that control and preventive measures, including restricted use of antibiotics, may not have been properly applied. On the other hand, the high levels of susceptibility to penicillin, ceftiofur, and cefalotin indicate that beta-lactams and cephalosporins are effective prophylactic and therapeutic options for control of bovine intramammary infections caused by this pathogen.

According to Myllys et al. (1994), antimicrobial resistance is an important factor in the introduction and dissemination of bacterial clones within a herd, with handling changes such as the implementation of systematic antibiotic treatment, stabling, and introduction of automatic milkers being closely associated, given their influence as selective forces on the pathogens responsible for mastitis.

A principal concern arising from increased antibiotic resistance among animal pathogens is that many of the organisms involved, including $S$. agalactiae, have zoonotic potential (FERREIRA et al., 2010; OLIVEIRA et al., 2011). Furthermore, resistance genes may be transferred horizontally to environmental microorganisms, those of the microbiota (MARTINEZ et al., 2009; WITTE, 2000), and even strictly human pathogens, limiting therapeutic options.

The present work contributes to our understanding of virulence, the dissemination of genetic resistance determinants, and antimicrobial susceptibility among $S$. agalactiae isolates associated with mastitis in Brazilian cattle. The results of this approach may aid the development of diagnostic, prophylactic, and therapeutic methods for pathologies caused by this bacterium, not only in cows, but also in humans and other affected species. 


\section{Conclusions}

Susceptibility to the tested antimicrobials varied, with high rates of resistance to tetracycline, amikacin, erythromycin, and clindamycin and low rates of resistance to cephalosporins, penicillin, and gentamicin.

Most of the isolates tested carried at least one of the genes ermB, tet $O$, and tet $M$, however, ermA, mefA, aphA3, and aad-6 were not detected. Associations were established between presence of the genes ermB, tet $M$, and tet $O$ and phenotypic resistance to erythromycin, clindamycin, and tetracycline.

\section{Acknowledgements}

We would like to acknowledge the $\mathrm{CNPq}$ and FAPEMIG for their support of projects APQ 02025/13 and BPD-00261/14.

\section{References}

BAL, E. B. B.; BAYAR, S.; BAL, M. A. Antimicrobial susceptibilities of Coagulase-Negative Staphylococci (CNS) and Streptococci from bovine subclinical mastitis cases. Journal of Microbiology, Seoul, v. 48, n. 3, p. 267 274, 2010.

BARLOW, J. Mastitis therapy and antimicrobial susceptibility: a multispecies review with a focus on antibiotic treatment of mastitis in dairy cattle. Journal of Mammary Gland Biology and Neoplasia, London, v. 16, n. 4, p. 383-407, 2011.

BOLUKAOTO, J. Y.; MONYAMA, C. M.; CHUKWU, M. O.; LEKALA, S. M.; NCHABELENG, M.; MALOBA, M. R.; MAVENYENGWA, R. T.; LEBELO, S. L.; MONOKOANE, S. T.; TSHEPUWANE, C.; MOYO, S. R. Antibiotic resistance of Streptococcus agalactiae isolated from pregnant women in Garankuwa, South Africa. BioMed Central Research Notes, London, v. 8, n. 364, p. 1-7, 2015.

CHOPRA, I.; ROBERTS, M. Tetracycline antibiotics: mode of action, applications, molecular biology, and epidemiology of bacterial resistance. Microbiology Molecular Biology Reviews, New York, v. 65, n. 2, p. 232-260, 2001.
CLERMONT, D.; CHESNEAU, O.; DE CESPÉDÈS, G.; HORAUD, T. New tetracycline resistance determinants coding for ribosomal protection in streptococci and nucleotide sequence of tet $(\mathrm{T})$ isolated from Streptococcus pyogenes A498. Antimicrobial Agents Chemotherapy, Washington, v. 419, n. 1, p. 112-116, 1997.

CLINICAL LABORATORY STANDARTS INSTITUTE - CLSI. Performance standards for antimicrobial disk susceptibility tests for bacteria isolated from animals: approved standard. $3^{\text {th }}$ ed. Wayne: Wayne Publishing, v. 28, 99 p. 2008. (CLSI Document M31-A3, 8).

CORREAA, A. B. A.; SILVA, L. G.; ABREU PINTO, T. C.; OLIVEIRA, I. C. M.; FERNANDES, F. G.; COSTA, N. S.; MATTOS, M. C.; FRACALANZZA, S. E. L.; BENCHETRIT, L. C. The genetic diversity and phenotypic characterization of Streptococcus agalactiae isolates from Rio de Janeiro, Brazil. Memórias do Instituto Oswaldo Cruz, Rio de Janeiro, v. 106, n. 8, p. 1002-1006, 2011.

DIPERSIO, L. P.; DIPERSIO, J. R. High rates of erythromycin and clindamycin resistance among OBGYN isolates of group B Streptococcus. Diagnostic Microbiology Infection Diseases, New York, v. 54, n. 1, p. 79-82, 2006.

DOGAN, B.; SCHUKKEN, Y. H.; SANTISTEBAN, C.; BOOR, K. J. Distribution of serotypes and antimicrobial resistance genes among Streptococcus agalactiae isolates from bovine and human hosts. Journal of Clinical Microbiology, Barcelona, v. 43, n. 12, p. 5899-5906, 2005.

DUARTE, R. S.; BELLEI, B. C.; MIRANDA, O. P.; BRITO, M. A. V. P.; TEIXEIRA, L. M. Distribution of antimicrobial resistance and virulence-related genes among Brazilian Group B streptococci recovered from bovine and human sources. Antimicrobial Agents Chemotherapy, Washington, v. 49, n. 1, p. 97-103, 2005.

DUARTE, R. S.; MIRANDA, O. P.; BELLEI, B. C.; BRITO, M. A.; TEIXEIRA, L. M. Phenotypic and molecular characteristics of Streptococcus agalactiae isolated recovered from milk of dairy cows in Brazil. Journal of Clinical Microbiology, Barcelona, v. 42, n. 9, p. 4214-4222, 2004.

DUTRA, V. G.; ALVES, V. M. N.; OLENDZKI, A. N.; DIAS, C. A. G.; BASTOS, A. F. A.; SANTOS, G. O.; AMORIN, E. L. T.; SOUSA, M. Â. B.; SANTOS, R.; RIBEIRO, P. C. S.; FONTES, C. F.; ANDREY, M.; MAGALHÃES, K.; ARAUJO, A. A.; PAFFADORE, L. F.; MARCONI, C.; MURTA, E. F. C.; FERNANDES JÚNIOR, P. C.; RADDI, M. S. G.; MARINHO, P. S.; BORNIA, B. G.; PALMEIRO, J. K.; DALLA- 
COSTA, L. M.; PINTO, T. C. A.; BOTELHO, A. C. N.; TEIXEIRA, L. M.; FRACALANZZA, S. E. L. Streptococcus agalactiae in Brazil: serotype distribution, virulence determinants and antimicrobial susceptibility. BMC Infectious Disease, London, v. 323, n. 14, p. 1-9, 2014.

ERSKINE, R. J.; WAGNER, S.; DEGRAVES, F. J. Mastitis therapy and pharmacology. Clinical Veterinary of North America Small Animal Practice, Philadelphia, v. 19, n. 1, p. 109-138, 2003.

EVANS, J. J.; KLESIUS, P. H.; GILBERT, P. M.; SHOEMAKER, C. A.; SARAWI, M. A. A. L.; LANDSBERG, J.; DUREMDEZ, R.; MARKOUK, A. A. L.; KENZI, S. A. L. Characterization of $\beta$-haemolitic group B Streptococcus agalactiae in cultured seabream, Sparus auratus L., and wild mullet, Liza klunzingeri (Day), in Kuwait. Journal of Fish Diseases, Oxford, v. 25, n. 9, p. 505-513, 2002.

FERREIRA, J. L.; PIGATTO, C. P.; ACCIOLI LINS, J. L. F. H.; AGUIAR FILHO, J. L. C.; CAVALCANTE, T. V. Bactérias causadoras de mastite subclínica em rebanhos leiteiros no município de Teresina, Piauí. Revista Científica Eletrônica de Medicina Veterinária, Garça, v. 8, n. 14, p. 1-13, 2010.

GAO, J.; YU, F. Q.; LUO, L. P.; HE, J. Z.; HOU, R. G.; ZHANG, H. Q.; LI, S. M.; SU, J. L.; HAN, B. Antibiotic resistance of Streptococcus agalactiae from cows with mastitis. The Veterinary Journal, London, v. 194, n. 3, p. 423-424, 2012.

GUÉRIN-FAUBLÉE，V.; TARDY，F.; BOUVERON, C.; CARRET, G. Antimicrobial susceptibility of Streptococcus species isolated from clinical mastitis in dairy cows. International Journal of Antimicrobial Agents, Amsterdam, v. 19, n. 3, p. 219-226, 2002.

HAENNI, M.; SARAS, E.; BERTIN, S.; LEBLOND, P.; MADEC, J. Y.; PAYOT, S. Diversity and mobility of integrative and conjugative elements in bovine isolates of Streptococcus agalactiae, S. dysgalactiae subsp. dysgalactiae, and S. uberis. Applied and Environmental Microbiology, Washington, v. 76, n. 24, p. 7957-7965, 2010.

HILLERTON, J. E.; LEIGH, J. A.; WARD, P. N.; COFFEY, T. J. Streptococcus agalactiae infections in dairy cows. Veterinary Record, London, v. 154, n. 21, p. 671-672, 2004.

JOHRI, A. K.; PAOLETI, L. C.; GLASER, P.; DUA, M.; SHARMA, P. K.; GRANDI, G.; RAPPUOLI, R. Group B Streptococcus: global incidence and vaccine development. Nature Reviews Microbiology, London, v. 4, n. 12, p. 932-942, 2006.
JOO, H. S.; FU, C.; OTTO, M. Bacterial strategies of resistance to antimicrobial peptides. Philosophical Transactions Royal Society Publishing B, London, v. 31, n.1965, p. 1-11, 2016.

KEEFE, G. Update on control of Staphylococcus aureus and Streptococcus agalactiae for management of mastitis. Veterinary Clinics Food Animal, Philadelphia, v. 28, n. 2, p. 203-216, 2012.

LINDEMAN, C. J.; PORTIS, E.; JOHANSEN, L.; MULLINS, L. M.; STOLTMAN, G. A. Susceptibility to antimicrobial agents among bovine mastitis pathogens isolated from North American dairy cattle, 2002-2010. Journal of Veterinary Diagnostic Investigation, Davis, v. 25, n. 5, p. 581-591, 2013.

MAIONE, D.; MARGARIT, I.; RINAUDO, C. D.; MASIGNANI, V.; MORA, M.; SCARSELLI, M.; TETTELIN, H.; BRETTONI, C.; IACOBINI, E. T.; ROSINI, R.; D'AGOSTINO, N.; MIORIN, L.; BUCCATO, S.; MARIANI, M.; GALLI, G.; NOGAROTTO, R.; NARDI-DEI, V.; VEGNI, F.; FRASER, C.; MANCUSO, G.; TETI, G.; MADOFF, L. C.; PAOLETTI, L. C.; RAPPUOLI, R.; KASPER, D. L.; TELFORD, J. L.; GRANDI, G. Identification of a universal group B Streptococcus vaccine by multiple genome screen. Science, Washington, v. 309. n. 5713, p. 148-150, 2005.

MARTINEZ, J. L.; FAJARDO, A.; GARMENDIA, L.; HERNANDEZ, A.; LINARES, J. F.; MARTÍNEZSOLANO, L.; SÁNCHEZ, M. B. A global view of antibiotic resistance. FEMS Microbiology Review, Delf, Holanda, v. 33, n. 1, p. 44-65, 2009.

MINST, K.; MÄRTLBAUER, E.; MILLER, T.; MEYER, C. Short communication: Streptococcus species isolated from mastitis milk samples in Germany and their resistance to antimicrobial agents. Journal of Dairy Science, Madison, v. 95, n. 12, p. 6957-6962, 2012.

MYLLYS, V.; HONKANEN-BUZALSKI, T.; HUOVINEN, P.; SANDHOLM, M.; NURMI, E. Association of changes in the bacterial ecology of bovine mastitis with changes in the use of milking machines and antibacterial drugs. Acta Veterinaria Scandinavica, Copenhagem, v. 35, n. 4, p. 363-369, 1994.

OLIVEIRA, C. M. C.; SOUSA, M. G. S.; SILVA E SILVA, N.; MENDONÇA, C. L.; SILVEIRA, J. A. S.; OAIGEN, R. P.; ANDRADE, S. J. T.; BARBOSA, J. D. Prevalência e etiologia da mastite bovina na bacia leiteira de Rondon do Pará, Estado do Pará. Pesquisa Veterinária Brasileira, Seropédica, v. 31, n. 2, p. 104-110, 2011.

OLIVEIRA, L.; RUEGG, P. L. Treatments of clinical mastitis occurring in cows on 51 large dairy herds in 
Wisconsin. Journal of Dairy Science, Madison, v. 97, n. 9, p. 5426-5436, 2014.

PALMEIRO, J. A K.; DALLA-COSTA, L. M.; FRACALANZZA, S. E. L.; BOTELHO, A. C. N.; NOGUEIRA, K. S.; SCHEFFER, M. C.; TORRES, R. S. L. A.; CARVALHO, N. S.; COGO, L. A. L. ; MADEIRA, H. M. F. Phenotypic and genotypic characterization of group B streptococcal isolates in southern Brazil. Journal of Clinical Microbiology, Barcelona, v. 48, n. 12, p. 4397-4403, 2010.

PINTO, T. C.; COSTA, N. S.; CORRÊA, A. B.; OLIVEIRA, I. C.; MATTOS, M. C.; ROSADO, A. S.; BENCHETRIT, L. C. Conjugative transfer of resistance determinants among human and bovine Streptococcus agalactiae. Brazilian Journal of Microbiology, São Paulo, v. 45, n. 3, p. 785-789, 2014.

PINTO, T. C.; COSTA, N. S.; VIANNA, S. A. R.; SILVA, L. G.; CORRÊA, A. B.; FERNANDES, F. G.; OLIVEIRA, I. C.; MATTOS, M. C.; ROSADO, A. S.; BENCHETRIT, L. C. Distribution of serotypes and evaluation of antimicrobial susceptibility among human and bovine Streptococcus agalactiae strains isolated in Brazil between 1980 and 2006. Brazilian Journal of Infectious Diseases, Salvador, v. 17, n. 2, p. 131-136, 2013.

POYART, C.; CELLI, J.; TRIEU-CUOT, P. Conjugative transposition of Tn916-related elements from Enterococcus faecalis to Escherichia coli and Pseudomonas fluorescens. Antimicrobial Agents Chemotherapy, Washington, v. 39, n. 2, p. 500-506, 1995.

POYART, C.; JARDY, L.; QUESNE, G.; BERCHE, P.; TRIEU-CUOT, P. Genetic basis of antibiotic resistance in Streptococcus agalactiae strains isolated in a French hospital. Antimicrobial Agents Chemotherapy, Washington, v. 47, n. 2, p. 794-797, 2003.

POYART-SALMERON, C.; CARLIER, C.; TRIEUCUOT, P.; COURTIEU, A. L.; COURVALIN, P. Transferable plasmid-mediated antibiotic resistance in Listeria monocytogenes. The Lancet, London, v. 335, n. 8703, p. 1422-1426, 1990.

RATO, M. G.; BEXIGA, R.; FLORINDO, C.; CAVACO, L. M.; VILELA, C. L.; SANTOS-SANCHES, I. Antimicrobial resistance and molecular epidemiology of streptococci from bovine mastitis. Veterinary Microbiology, Barcelona, v. 161. n. 3-4, p. 286-294, 2013.

RIBEIRO, M. G.; COSTA, E. O.; LEITE, D. S.; LANGONI, H.; GARINO JÚNIOR, F.; VICTÓRIA, C.; LISTONI, F. J. P. Fatores de virulência em linhagens de Escherichia coli isoladas de mastite bovina. Arquivo Brasileiro de Medicina Veterinária e Zootecnia, Belo Horizonte, v. 58, n. 5, p. 724-731, 2006.

ROBERTS, M. C. Update on macrolide-lincosamidestreptogramin, ketolide and oxazolidinone resistance genes. FEMS Microbiology Letters, Delf, v. 282, n. 2, p. 147-159, 2008.

RUEGG, P. L. New perspectives in udder health management. Veterinary Clinics North America: Food Animal Practice, Philadelphia, v. 28, n. 2, p. 149-163, 2012.

SADOWY, E.; MATYNIA, B.; HRYNIEWICZ, W. Population structure, virulence factors and resistance determinants of invasive, non-invasive and colonizing Streptococcus agalactiae in Poland. Journal of Antimicrobial Chemotherapy, London, v. 65, n. 9, p. 1907-1914, 2010.

SANTOS, M. V.; FONSECA, L. F. L. Estratégias para controle da mastite e melhoria da qualidade do leite. São Paulo: Manole, 2007. 314 p.

SCHWARZ, S.; KEHRENBERG, C.; WALSH, T. R. Use of antimicrobial agents in veterinary medicine and food animal production. International Journal of Antimicrobial Agents, Amsterdam, v. 17, n. 6, p. 431437, 2001.

SUTCLIFFE, J.; GREBE, T.; TAIT-KAMRADT, A.; WONDRACK, L. Detection of erythromycin-resistant determinants by PCR. Antimicrobial Agents and Chemotherapy, Washington, v. 40, n. 11, p. 2562-2566, 1996.

TENHAGEN, B. A.; KÖSTER, G.; WALLMANN, J.; HEUWIESER, W. Prevalence of mastitis pathogens and their resistance against antimicrobial agents in dairy cows in Brandenburg, Journal of Dairy Science, Madison, v. 89, n. 7, p. 2542-2551, 2006.

VARALDO, P. E.; MONTANARI, M. P.; GIOVANETTI, E. Genetic elements responsible for erythromycin resistance in streptococci. Antimicrobial Agents and Chemotherapy, Washington, v. 53, n. 2, p. 343-353, 2009.

VERANI, J. R.; MCGEE, L.; SCHRAG, S. J. Prevention of Perinatal Group B Streptococcal disease: revised guidelines from CDC, Morbidity and Mortality Weekly Report, v. 59, p. 1-36, 2010.

VINTOV, J.; AARESTRUP, F. M.; ZINN, C. E.; OLSEN, J. E. Association between phage types and antimicrobial resistance among bovine Staphylococcus aureus from 10 countries. Veterinary Microbiology, Barcelona, v. 95, n. 1-2, p. 133-147, 2003. 
WITTE, W. Ecological impact of antibiotic use in animals on different complex microflora: environment. International Journal of Antimicrobial Agents, Amsterdam, v. 14, n. 4, p. 321-325, 2000.

ZADOKS, R. N.; MIDDLETON, J. R.; MCDOUGALL,
S.; KATHOLM, J.; SCHUKKEN, Y. H. Molecular epidemiology of mastitis pathogens of dairy cattle and comparative relevance to humans. Journal of Mammary Gland Biology and Neoplasia, London, v. 16, n. 4, p. 357-372, 2011. 
